\title{
Marble Industry Sentra Design In South Aceh Regency
}

\author{
Resky Rusnanda ${ }^{a, 1}$, Oktalia Triananda Lovita ${ }^{b, 2}$ \\ ${ }^{a}$ Politeknik Aceh Selatan, Jl. Merdeka. Ruko Reklamasi Pantai, Tapaktuan \\ ${ }^{b}$ Politeknik Aceh Selatan, Jl. Merdeka. Ruko Reklamasi Pantai, Tapaktuan \\ Iofficial.reskyrusnanda@gmail.com, ${ }^{2}$ oktalia.t.lovita@gmail.com
}

ARTICLE INFO

Article history:

Received

Keywords:

Marble Industry, Sustainable Architecture, Marble Stone, Marble Waste, Design Concept

\section{ABSTRACT}

Indonesia has a variety of crops, especially in the field of rocks, some of which are famous to the corners of the world one of them is Marble Stone. Kabupaten Aceh Selatan, is also one of the marbleproducing locations in Aceh Province. Tapaktuan sub-district is one of marble stone processing center in South Aceh regency. The location of marble processing in Tapaktuan City is currently located at UPT Marble Polytechnic of South Aceh campus. Processing industry in UPT marble Poltas are included in medium scale industries which use tools with large capacity and sufficient for processing of marble stone. However, there are some problems that arise due to the activity of marble process. Among them, the occurrence of environmental pollution derived from the process of making marble handicrafts. Waste generated from cutting, smelting, polishing, resulting in a solution of water mixed with lime which is a problem for the environment, as well as disturbing the surrounding community for causing noise and pollution. The purpose of this research is to produce the design of industrial center of marble in South Aceh regency applying the concept of Sustainable Architecture, which can reduce the impact of natural damage due to the processing of marble stone. The method used is the concept of sustainable Architecture. The results of this study include the design of landscape central marble industry.

Copyright (C) 2018 Politeknik Aceh Selatan. All rights reserved.

\section{Introduction}

Indonesia has a variety of crops, especially in the field of rocks, some of which are famous to the corners of the world one of them is Marble Stone. South Aceh Regency, is also one of the marble producers in Aceh province which has dominance of color and pattern that is different from other marble producing cities.

Tapaktuan sub-district is one of marble stone processing center in South Aceh regency. The location of marble processing in Tapaktuan City is currently located at UPT Marble Polytechnic of South Aceh campus. Processing industry in UPT marble Poltas are included in medium scale industries which use tools with large capacity and sufficient for processing of marble stone.

This marble industry is a superior city posttensions that we can make as a main commodity in the field of middle industry in South Aceh and make city of Tapaktuan as center of marble industry. This refers to the availability of existing marble raw materials, and can have a good impact on the economy of the city in particular and the economy of the general public.

However, there are some problems that arise due to the activity of marble process. Among them, the occurrence of environmental pollution derived from the process of making marble 
handicrafts. Waste generated from cutting, smelting, polishing, resulting in a solution of water mixed with lime which is a problem for the environment, and disrupt the surrounding community for causing noise. These environmental impacts are caused by several factors, one of which is no careful planning on the location and arrangement of the marble industry factory, so it does not integrate well the disposal of industrial and environmental waste around the factory.

Therefore, researchers want to make good and integrated planning, both in terms of location and plant layout plan, which will be expected to reduce the environmental impact, and make Tapaktuan as the main center of marble industry in Aceh Province.

\section{Literature}

\section{Understanding Sentra}

According to a large Indonesian dictionary (2010), central is place that is located in the middle or bias called the center, the center in question is as the main place of the management of marble stones [1].

\section{Understanding Industry}

Industry is a business or processing activity of raw materials or semi-finished goods into finished goods that have added value to gain profit. Assembling and reparations are part of the industry. The results of the industry are not only in the form of goods, but also in the form of services.

\section{Industrial Estate}

The Urban Land Institute, Washington DC (1975) industrial estate is an area or region that is usually dominated by industrial activity. Industrial zones typically have combined facilities comprising plant equipment, research and laboratories for development, office buildings, banks and other infrastructure such as social and public facilities covering offices, housing, and others.

The term industrial estate in Indonesia is still relatively new. The term is used to express an understanding of the place of centralization of industrial enterprise groups in a separate area. Industrial area is intended as an equivalent of industrial estates. Previously, such industrial groupings were called "industrial environments".

\section{Marble Stone}

Marble is a rough crystal stone derived from limestone or dolomite. The pure marble is white and is mainly composed by calcite minerals. Marble or marble is the result of metamorphic or transition from limestone. The influence of temperature and pressure generated by the endogenous forces cause recrystallization in the rock to form foliasi or not foliasi.

\section{Architectural Design Theory}

According to Neufert (2003) on plant or warehousing planning, the approximate space requirement of the data provided by the owner usually includes the following: 1) Potential for building expansion. 2) Vehicle parking patterns for guests or visitors, employees and trucking vehicles. 3) Outdoor warehouse area or open warehouse. 4) Gardening planning. 5) Pattern of achievement from highway, rail and boat dock. 6) National and local regulations. 7) Estimate the impact of environmental impacts.

The 1:1 plot ratio is the minimum ratio on all types of treads including for industrial buildings with offices. The closed area of the site is recommended not more than $75 \%$ of the available area: acceptable conditions range from $50-60 \%$ only. The enclosed area does not include calculations for the vehicle's circulation path [2]. 
6. Theory of Industrial Land Allocation

Determinants of the location of quality of a region associated with the attractiveness of the region to investment decisions of potential investors that already exist. Many factors are used as consideration to determine where should the appropriate industrial location.

While according to Weber are: 1) Transportation costs, Transportation costs increase proportionally with distance so that the lowest point for transportation costs is the point that shows the minimum cost for raw material transportation and distribution of production. 2) Wage costs, producers tend to look for locations with lower wage rates in economic activity while workers tend to seek locations with higher wage concentrations. 3) Spatial profit and concentration of industry Spatial concentration will create benefits in the form of savings of localization and saving of urbanization [3].

\section{Basic Theory of Sustainable Architecture}

Sustainable Architecture aspects are the brainchild of some communities who care about the sustainability of resources. The community is part of a company or union of countries in the world. The basic principles of sustainable Architecture are 1) Environmental Sustainability. 2) Social Sustainability. 3) Economic Sustainability [3].

\section{Methode}

The method used in the design of marble centers in the district of South Aceh is the concept of sustainable Architecture which in this concept apply the principles of Environmental Sustainability, Social Sustainability, and Economic Sustainability

\section{Results and Discussion}

1. Analysis of Area Conditions

The selection of treads in the design of the marble industry center considers its function as a center of industry and business to increase the economic value of the community, especially in Samadua Sub-district, and it also functions as a Pilot Project of marble industry in South Aceh Regency in particular and Aceh Province Generally.

\section{Locations of Regions}

Site Selection The design of the marble industry center located in South Aceh Regency is located in the new campus of Polytechnic of South Aceh in Mount Ribee, Samadua District, South Aceh Regency.

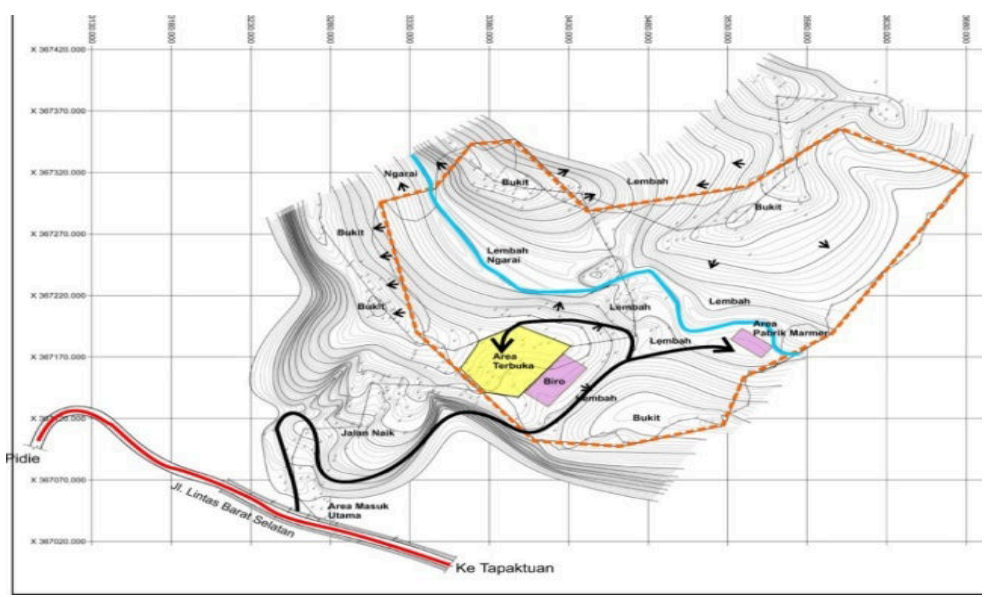

Fig.1. Research sites 
The analysis of the location of the marble industry center as the table below:

Table.1. Location Analysis Research

\begin{tabular}{|c|c|c|c|}
\hline No & Variabel & Indikator & $\begin{array}{l}\text { Kawasan } \\
\text { Penelitian }\end{array}$ \\
\hline 1 & $\begin{array}{l}\text { Distance city center Min } 10 \mathrm{~km} \\
\text { accordingly }\end{array}$ & Min $10 \mathrm{~km}$ & corresponding \\
\hline 2 & $\begin{array}{l}\text { Distance to the Compact } \\
\text { settlement residents }\end{array}$ & Min $2 \mathrm{~km}$ & corresponding \\
\hline 3 & The road network serves & Primary artery & corresponding \\
\hline 4 & Network system that serves & $\begin{array}{l}\text { Electricity and } \\
\text { telecommunications } \\
\text { network }\end{array}$ & corresponding \\
\hline 5 & Transportation infrastructure & Available seaports & corresponding \\
\hline 6 & $\begin{array}{l}\text { Topography / slope of the } \\
\text { ground }\end{array}$ & Maks $15 \%$ & corresponding \\
\hline 7 & Network against the river & Maks 5km & corresponding \\
\hline 8 & Land carrying capacity & $\begin{array}{l}\text { Sigma ground } 0.7-1.0 \mathrm{~kg} / \\
\mathrm{cm}\end{array}$ & corresponding \\
\hline 9 & Soil fertility & Relatively infertile & corresponding \\
\hline 10 & Land allotment & $\begin{array}{l}\text { Non-residential, non- } \\
\text { agricultural and non- } \\
\text { conservation }\end{array}$ & corresponding \\
\hline 13 & Location orientation & $\begin{array}{l}\text { Accessibility is high and } \\
\text { close to potential workforce }\end{array}$ & corresponding \\
\hline 14 & Transportation costs & $\begin{array}{l}\text { Minimum distance with raw } \\
\text { materials }\end{array}$ & corresponding \\
\hline 15 & Wage Fee & Low wage locations & corresponding \\
\hline 14 & Multiplier effects & $\begin{array}{l}\text { Industrial land requirements } \\
\text { and the multiplier }=2 \mathrm{x}, \\
\text { Home needs } 1.5 \mathrm{tk}-1 \mathrm{kk} \text {, } \\
\text { needs fasum and fasos }\end{array}$ & corresponding \\
\hline
\end{tabular}

3. Existing Area Condition

- Limits of Design 
From the results of direct observations made, locomotive industry center Marble samadua District, with an area of \pm 1 hectare

- Accessibility

Treads are on the road so they are easily accessible by four-wheelers, motorists, and pedestrians. Kurnag road width of more than 7 meters, road conditions are in good condition (asphalt). Access tapak is the main access to Polytechnic of South Aceh Campus.

- Topography altitude

land location of planning with main road parallel

- View

view of the marble center plan in South Aceh District is a national crossroads, where it is vast ocean that can add to the uniqueness of this marble center location.

- Utilities

In terms of utility, the location of this marble center is not sufficient, so it needs to be considered especially for the supporting facilities of the marble industry.

4. Building Analysis

- Function Analysis

The functions to be analyzed in the design of the Marble stone industry center in South Aceh Regency are grouped based on the type of activities and needs of its users. The functions as follows:

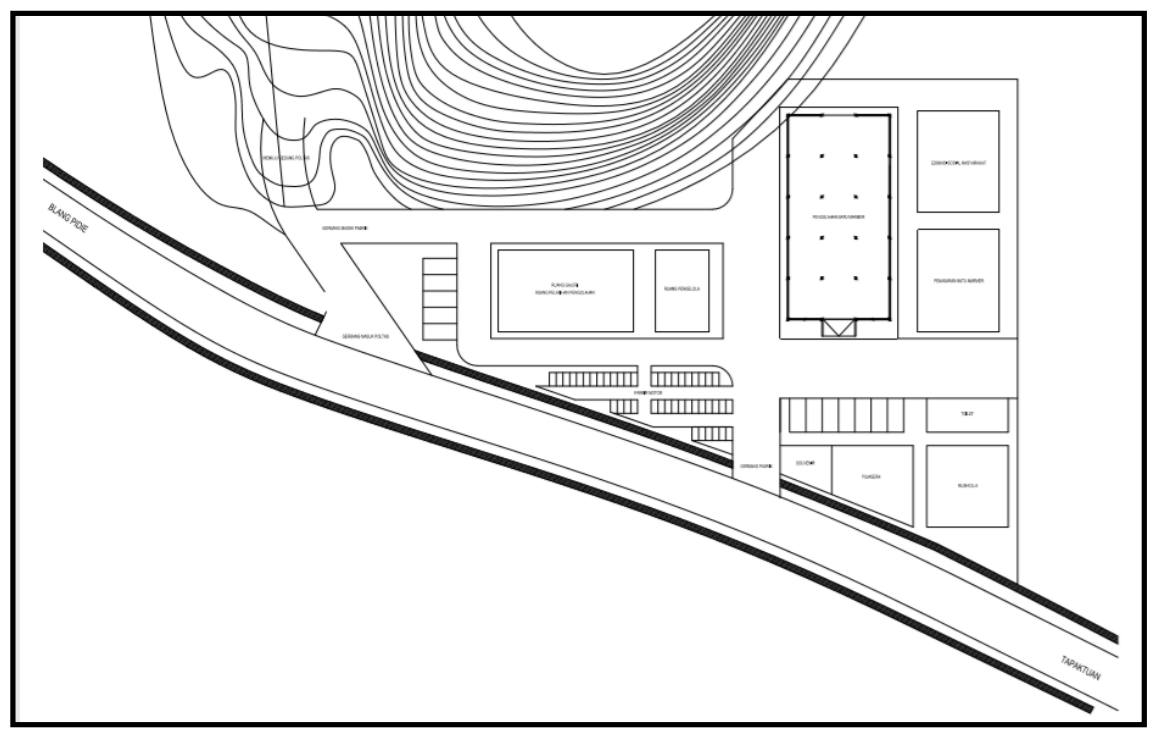

Fig.2. Site Design

5. Building Concept Analysis

The basic concept used in designing the center of marble industry is Sustainable Architecture. Where this concept takes into account Environmental Sustainability, Social Sustainability and Economic Sustainability. Analysis to this concept can be seen on: 


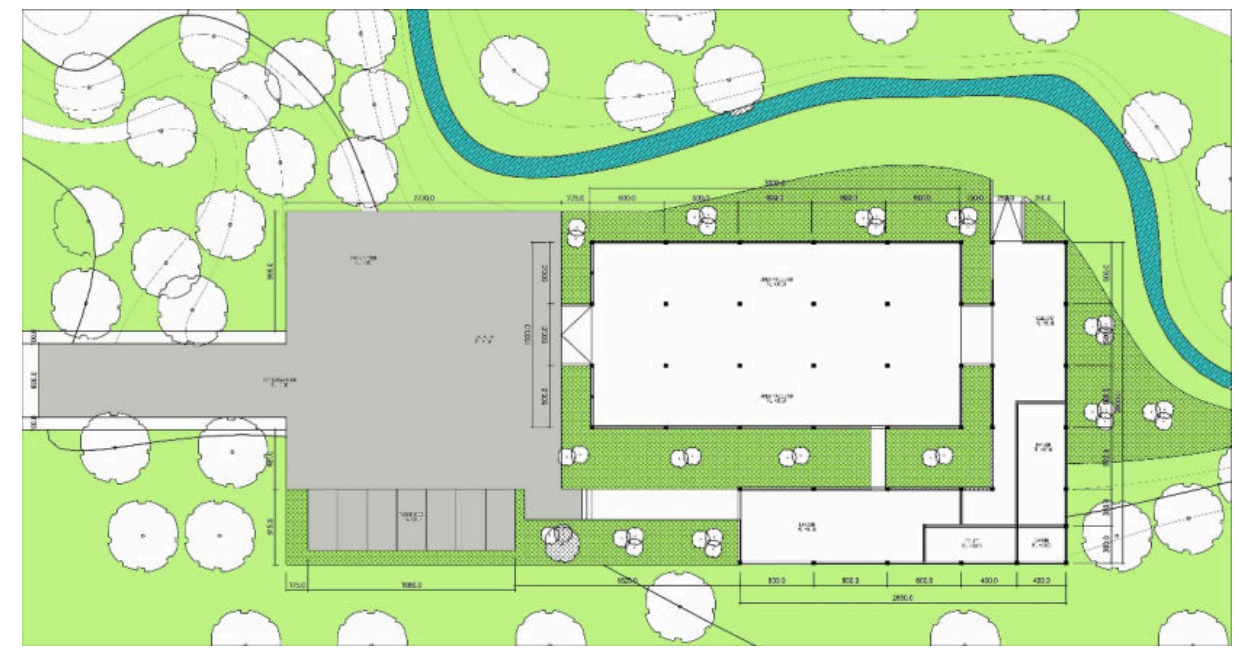

Fig.3. Building Landscape

\section{Conclussion}

The conclusion of this research is that the design of marble industry center in South Aceh District is using the theme of Architecture Sustainable. Where to take into account all aspects of planning include Environmental Sustainability, Social Sustainability and Economic Sustainability. The purpose of this design is to minimize and manage industrial waste generated by marble cutting activities, as well as to arrange every function of the activities in the marble industry.

\section{References}

[1] Anonim. 2015. Kamus Besar Bahasa Indonesia Online. http://kbbi.web.id (access at 19 January 2018. Time 14.35.

[2] Neufert, Ernest. 2003. Data Arsitek Jilid I. Jakarta: Erlangga.

[3] Neufert, Ernest. 2003. Data Arsitek Jilid II. Jakarta: Erlangga. 